\title{
In Vitro RNA-dependent RNA Synthesis by a Curde Enzyme Fraction Isolated from Normal Rat Livers
}

\author{
Hiroto Naora \\ Molecular Biology Unit, Research School of Biological Sciences, The Australian \\ National University, Canberra, A.C.T., 2601, (Australia)
}

\begin{abstract}
A crude enzyme preparation from "uninfected" rat livers can catalyze the synthesis of RNA when rat liver mRNA or nuclear RNA is added to the system. The newly synthesized RNA contains sequences complementary to those of the RNA template and, after phenol extraction, is found to be partially hydrogen-bonded to the added poly (A)-containing RNA. The possibility of message amplification in normal cells is discussed.
\end{abstract}

The belief to date is largely that in higher organisms, RNA is synthesized only on a DNA template by a DNA-dependent RNA polymerase, exceptions being RNA virus-infected cells, where it has been shown that a viral RNA-dependent RNA polymerase is responsible for viral RNA synthesis $(1,2)$. However, the possibility of RNA-dependent RNA synthesis being involved in normal cellular function has been described $(3,4)$. Recently an enzyme fraction, crude or partially purified from "uninfected" animal and plant tissues, was reported, which catalyzed the in vitro synthesis of RNA after addition of RNA but not DNA (5-9).

In this communication I describe an in vitro RNA-dependent RNA synthesis by a crude enzyme fraction isolated from "uninfected" rat livers. The result suggests that the enzyme product after phenol extraction was in part hydrogen-bonded to poly (A)containing RNA which had been added to the reaction mixture and which was probably acting as a template.

\section{MATERIALS AND METHODS}

Materials. $\left[5,6{ }^{3} \mathrm{H}\right]$ Uridine-5'-triphosphate $(52 \mathrm{Ci} / \mathrm{mmole})$ and $\left[\alpha^{-32} \mathrm{P}\right]$ uridine-5'-triphosphate $(1.1 \mathrm{Ci} / \mathrm{mmole})$ were purchased from the Radiochemical Centre, Amersham. Ribonuclease $T_{1}$, pancreatic ribonuclease $A$, deoxyribonuclease and oligo (dT)-cellulose were the same as those used in the previous publication (10). Poly (A), poly (U), poly (C) and poly (U, C) were from Miles Co. Rifampicin (Ciba Ltd.) and $\alpha$-amanitin were donated by my colleague, Dr. P. Goodwin. Male Wistar rats (150-188 gm body weight) were used.

Preparation of RNA's. Unlabelled nuclear RNA (nRNA), double-stranded RNA (dsRNA), 28S rRNA and tRNA were prepared from rat livers by the procedures described previously $(10,11)$. Unlabelled mRNA was purified from rat liver polysomal RNA by sucrose density gradient centrifugation (10). Reovirus RNA was the same preparation as used in the previous publication (11).

Preparation of enzyme fraction. An enzyme fraction was prepared from rat livers by a modification of the method of Haruna et al (12). Fresh livers were passed through a mesh, suspended in Buffer A (100 mM Tris- $\mathrm{HCl}, \mathrm{pH}$ 7.4, $10 \mathrm{mM} \mathrm{MgCl}_{2}, 0.5 \mathrm{mM}$ mercaptoethanol 
and $5 \mu \mathrm{g} / \mathrm{ml}$ deoxyribonuclease) and homogenized in a Waring blender after freezing and thawing. The post-mitochondrial supernatant obtained by centrifugation at 30,000xg for $30 \mathrm{~min}$ was treated with $0.11 \mathrm{M}$ EDTA for $5 \mathrm{~min}$ at $2^{\circ} \mathrm{C}$ and then clarified by centrifugation. The supernatant containing the solubilized enzyme was brought to $50 \%$ saturation with ammonium sulphate. The precipitate was collected by centrifugation at $17,000 \times \mathrm{xg}$ for $10 \mathrm{~min}$, dissolved in Buffer $\mathrm{B}\left(10 \mathrm{mM}\right.$ Tris- $\mathrm{HCl}, \mathrm{pH} 7.4,5 \mathrm{mM} \mathrm{MgCl}_{2}, 0.5 \mathrm{mM}$ mercaptoethanol, $0.4 \mathrm{M}\left(\mathrm{NH}_{4}\right)_{2} \mathrm{SO}_{4}$ and $20 \%$ (v/v) glycerol) and stored at $-80^{\circ} \mathrm{C}$.

Assay for enzyme activity. The standard reaction mixture contained in a final volume of $0.25 \mathrm{ml}: 80 \mathrm{mM}$ Tris- $\mathrm{HCl}$, pH 7.9, $1.5 \mathrm{mM} \mathrm{MgCl}_{2}, 0.6 \mathrm{mM} \mathrm{MnCl}, 0.4 \mathrm{mM}$ ATP, GTP and CTP, $0.08 \mathrm{mM}$ labelled UTP $\left(10 \mu \mathrm{C}{ }^{3} \mathrm{H}\right.$ or approx. $20 \mu \mathrm{C}{ }^{32} \mathrm{P}$-labelled UTP), $2.5 \mu \mathrm{g}$ actinomycin D, unless otherwise indicated 65-67 $\mu \mathrm{g}$ nRNA, and 144-158 $\mu \mathrm{g}$ enzyme. After incubation at $36^{\circ} \mathrm{C}$ for 20 min (unless otherwise noted), the reaction was stopped by addition of pyrophosphate and trichloroacetic acid (12). The precipitate was collected on a glass-fiber filter and the radioactivity determined as described previously (11).

Preparation of enzyme product. After incubation in 5 to 10 -fold standard reaction mixtures at $36^{\circ} \mathrm{C}$ for $20 \mathrm{~min}$, labelled RNA was extracted by the sodium dodecyl sulphate-phenol procedure (13). The aqueous layer obtained after phenol extraction followed by centrifugation at 9,000xg for $10 \mathrm{~min}$ was collected and dialyzed against $10 \mathrm{mM}$ Tris- $\mathrm{HCl}, \mathrm{pH} \mathrm{7.6}$, $0.14 \mathrm{M} \mathrm{NaCl}$ for $18 \mathrm{hrs}$. The labelled material was precipitated with 2 volumes of absolute ethanol, washed with $80 \%$ ethanol several times, dissolved in $10 \mathrm{mM}$ Tris- $\mathrm{HCl}$ or phosphate buffer, $\mathrm{pH} 7.4$ and stored at $-20^{\circ} \mathrm{C}$. The labelled material obtained under these conditionshereafter called "enzyme products"- - contained both nRNA added to the reaction mixture and newly synthesized RNA containing labelled UMP.

Analysis of nucleoside and nucleotide content. Nucleotide content of ${ }^{32} \mathrm{P}$-labelled enzyme product was analyzed by the method described previously (11). Labelled uridine and UMP content of ${ }^{3} \mathrm{H}$-labelled enzyme product were determined by one dimensional chromatography on thin-layer cellulose plates using the development solution $(66 \%$ isobutyric acid and $1 \%$ ammonia dissolved in distilled water).

$R N A-R N A$ hybridization. Hybridization was carried out at $72^{\circ} \mathrm{C}$ for $24 \mathrm{hrs}$ in $10 \mathrm{mM}$ phosphate buffer, $\mathrm{pH} 7.6,0.3 \mathrm{M} \mathrm{NaCl}$. After annealing, the reaction mixtures were treated with ribonucleases and the radioactivity of the hybrids formed was determined as described previously (10).

Oligo $(d T)$-cellulose column chromatography. This was carried out by the method previously described (10). Non-poly (A) and poly (A)-containing RNA fractions of enzyme products were obtained by washing the column with $10 \mathrm{mM}$ Tris- $\mathrm{HCl}, \mathrm{pH} 7.6,0.5 \mathrm{M} \mathrm{NaCl}$ and by eluting with $10 \mathrm{mM}$ Tris- $\mathrm{HCl}, \mathrm{pH} 7.6$, respectively.

\section{RESULTS AND DISCUSSION}

Some properties of the incorporation systems. In the standard reaction mixture, ${ }^{3} \mathrm{H}-\mathrm{UTP}$ was incorporated into the acid-insoluble fraction as shown in Fig. 1. Omission of nRNA from the reaction mixture abolished ${ }^{3} \mathrm{H}-\mathrm{UTP}$ incorporation, indicating an almost absolute requirement for added RNA for the reaction. Removal of actinomycin $\mathrm{D}$ from the reaction mixture resulted in a slight (less than $10 \%$ ) enhancement of ${ }^{3} \mathrm{H}$-UTP incorporation. The reaction was optimal at $\mathrm{pH} 7.9$ and showed a definite requirement for $\mathrm{Mn}^{++}$. Maximum activity was seen at a concentration of $0.6 \mathrm{mM}$ $\mathrm{Mn}^{++}$in the presence of $1.5 \mathrm{mM} \mathrm{Mg}^{++}$(Fig. 2).

The enzyme(s) showed some characteristics expected of an RNA-dependent RNA polymerase (2) or a similar type of enzyme (Table 1). The reaction was not significantly affected by orthophosphate, $\alpha$-amanitin, rifampicin or deoxyribonuclease, 


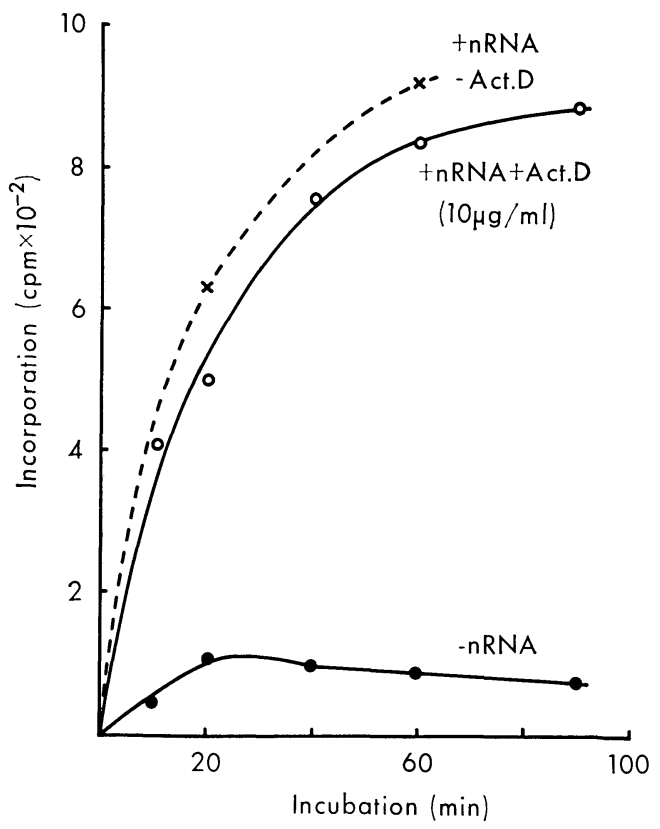

Fig. 1. The effect of added nRNA on the kinetics of ${ }^{3} \mathrm{H}-\mathrm{UTP}$ incorporation. The composition of the standard reaction mixture was as in the text with the following exception. $\bigcirc-\bigcirc$, with 216 $\mu \mathrm{g} / \mathrm{ml} \mathrm{nRNA}$ and $10 \mu \mathrm{g} / \mathrm{ml}$ actinomycin D.; - $\bullet$, without nRNA; $\times-\cdots \times$, with $216 \mu \mathrm{g} / \mathrm{ml} \mathrm{nRNA}$, but without actinomycin $\mathrm{D}$.

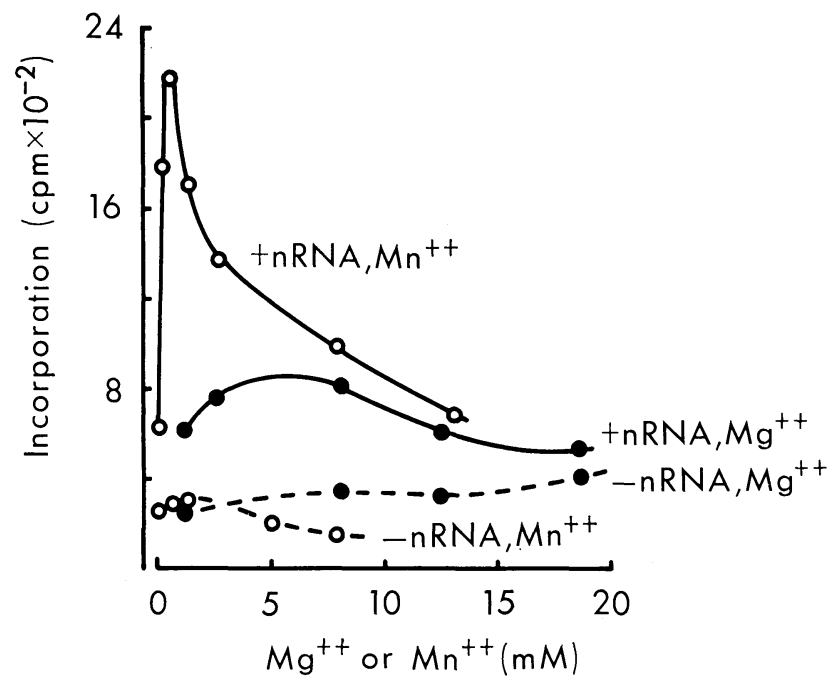

Fig. 2. The effect of varying concentrations of $\mathrm{Mg}^{++}$or $\mathrm{Mn}^{++}$on ${ }^{3} \mathrm{H}-\mathrm{UTP}$ incorporation. Assay conditions were as in the text except for the concentration of divalent cations and nRNA. $O-O$, with or $\mathrm{O}_{--\mathrm{O}}$, without $268 \mu \mathrm{g} / \mathrm{ml} \mathrm{nRNA}$, but at varied concentration of $\mathrm{Mn}^{++}$in the presence of $1.5 \mathrm{mM} \mathrm{MgCl} 2$; $\bullet$, with or $-\cdots$, without $268 \mu \mathrm{g} / \mathrm{ml} \mathrm{nRNA}$, but at varied concentration of $\mathrm{Mg}^{++}$. 
excluding any significant contribution of polynucleotide phosphorylase or DNAdependent RNA polymerase. Enzyme activity was markedly inhibited by the addition of ribonuclease or inorganic pyrophosphate.

TABLE 1. THE EFFECTS OF INHIBITORS ON RNA-DEPENDENT RNA SYNTHESIS

\begin{tabular}{cc}
\hline Inhibitors & $\begin{array}{c}\text { Relative } \\
\text { incorporation }\end{array}$ \\
\hline Control (no inhibitor) & 100 \\
+ Pyrophosphate $(1.1 \mathrm{mM})$ & 16 \\
$+\quad(8 \mathrm{mM})$ & 2 \\
+ Orthophosphate $(1.2 \mathrm{mM})$ & 97 \\
$+\quad(10 \mathrm{mM})$ & 70 \\
$+\alpha$-amanitin $(0.4 \mu \mathrm{g} / \mathrm{ml})$ & 100 \\
$+\quad, \quad(4.0 \mu \mathrm{g} / \mathrm{ml})$ & 91 \\
+ Rifampicin $(4.0 \mu \mathrm{g} / \mathrm{ml})$ & 79 \\
+ Deoxyribonuclease $(53 \mu \mathrm{g} / \mathrm{ml})$ & 98 \\
+ Ribonuclease A $(12 \mu \mathrm{g} / \mathrm{ml})$ & 2 \\
\hline
\end{tabular}

The standard reaction mixtures were as described in the text except for the addition of inhibitors as indicated. The control value was $1801 \mathrm{cpm}$.

Stimulatory activities of RNA and DNA. The stimulatory activity of synthetic and natural polynucleotides varied considerably (Table 2). Neither native nor denatured

TABLE 2. StimUlatory ACtivities OF RNA AND DNA

\begin{tabular}{lc}
\multicolumn{1}{c}{ Addition } & $\begin{array}{c}\text { Relative } \\
\text { incorporation }\end{array}$ \\
\hline Control (no RNA or DNA) & 100 \\
DNA, rat liver (undenatured, $40 \mu \mathrm{g} / \mathrm{ml})$ & 101 \\
(heat-denatured, $40 \mu \mathrm{g} / \mathrm{ml})$ & 95 \\
nRNA $(40 \mu \mathrm{g} / \mathrm{ml})$ & 421 \\
tRNA $(40 \mu \mathrm{g} / \mathrm{ml})$ & 267 \\
28S rRNA $(39 \mu \mathrm{g} / \mathrm{ml})$ & 240 \\
dsRNA $(53 \mu \mathrm{g} / \mathrm{ml})$ & 93 \\
Reovirus RNA $(34 \mu \mathrm{g} / \mathrm{ml})$ & 101 \\
Poly (A)·Poly $(\mathrm{U})(200 \mu \mathrm{g} / \mathrm{ml})$ & 77 \\
Poly (A) $(100 \mu \mathrm{g} / \mathrm{ml})$ & 108 \\
Poly (U) $(100 \mu \mathrm{g} / \mathrm{ml})$ & 147 \\
Poly (C) $(100 \mu \mathrm{g} / \mathrm{ml})$ & 85 \\
Poly (U, C) $(100 \mu \mathrm{g} / \mathrm{ml})$ & 122 \\
\hline
\end{tabular}

The standard reaction mixtures were as described in the text except for the addition or omission of RNA or DNA as indicated. The control values ranged from 328 to $443 \mathrm{cpm}$ in several experiments.

rat liver DNA showed any stimulatory activity. Marked stimulation was observed when rat liver nRNA or mRNA was added to the reaction mixture. The stimulation was dose-dependent (Fig. 3). The preparation of rat liver mRNA used in this experiment was highly purified and had been shown to contain messages for liver cellular proteins (10). On the other hand, the nRNA preparation contained a variety of RNA species in addition to heterogeneous nuclear RNA (HnRNA). Therefore, no precise comparison of efficiency of stimulation can be made between mRNA and nRNA. 


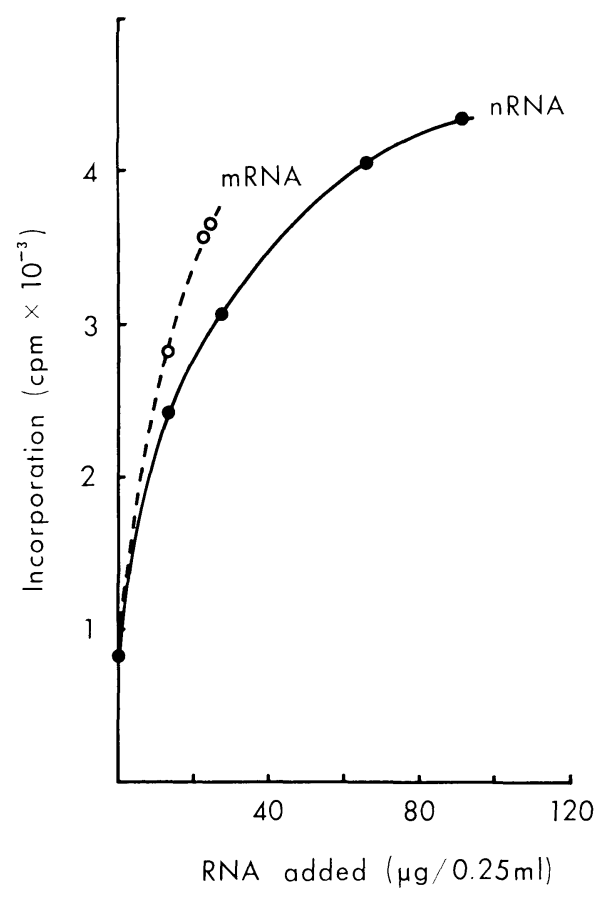

Fig. 3. The effect of varying amounts of added RNA on ${ }^{3} \mathrm{H}-\mathrm{UTP}$ incorporation. Assay conditions were described in the text except for the amounts of mRNA $(0 \cdots 0)$ or nRNA

28S rRNA and tRNA exhibited low stimulatory activities. No significant stimulation of ${ }^{3} \mathrm{H}$-UTP incorporation was observed with any of the synthetic RNAs used. Under standard assay conditions, all dsRNAs were inactive. Since nRNA effected good stimulation, unless otherwise stated, nRNA was routinely used for further investigations.

Characterization of the enzyme product. Since the enzyme products are completely sensitive to $0.3 \mathrm{~N} \mathrm{KOH}$, this is indicative of RNA species which incorporated labelled UMP. Moreover, the majority $(98.4 \%)$ of the product was found to be single-stranded RNA and only $1.6 \%$ was ribonuclease-resistant (Table 3 ). This resistance was abolished when the enzyme products were heat-denatured before ribonuclease treatment using conditions which were specifically established for isolation of dsRNA (11). This indicates that a small portion of the newly synthesized RNA molecules is part of double-stranded structures. It is not clear whether this complex represents an in situ ribonuclease-resistant structure or a self-annealed artefact which occurred during phenol extraction $(14,15)$. The possibility exists that complementary copies may be formed on the templates and after phenol extraction these copies are partially hydrogen-bonded to the template. This case is analogous to that of viral RNA replication (2) and was supported by the results obtained in several experiments. 


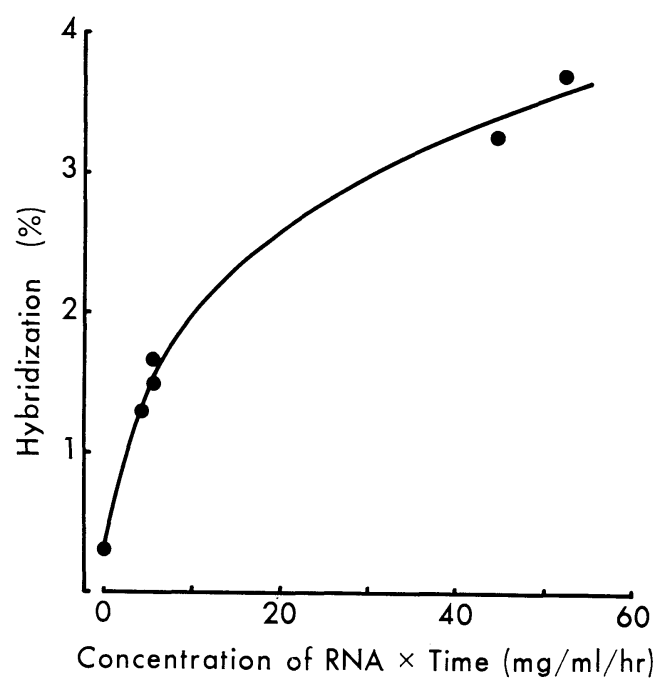

Fig. 4. Hybridization of labelled enzyme products at varying inputs of RNA. Enzyme products were prepared from 5-fold standard reaction mixtures which contained labelled UTP with unlabelled ATP, GTP and CTP (- - ). Hybridization was carried out as described in the text.

TABLE 3. RIBONUCLEASE SENSITIVITY OF ENZYME PRODUCTS

\begin{tabular}{lrc}
\hline \multirow{2}{*}{ Treatment } & \multicolumn{2}{c}{${ }^{3}$ H-labelled product remaining } \\
\cline { 2 - 3 } & $(\mathrm{cpm})$ & $(\%)$ \\
\hline Control (no treatment) & 6904 & 100 \\
Ribonuclease treatment & 122 & 1.6 \\
$\begin{array}{c}\text { Heat-denaturation, followed by } \\
\text { ribonuclease treatment }\end{array}$ & 20 & 0.3 \\
\hline
\end{tabular}

${ }^{3} \mathrm{H}$-Labelled enzyme products were prepared as described in the text. The ribonuclease treatment was carried out with ribonuclease A $(10 \mu \mathrm{g} / \mathrm{ml})$, and ribonuclease $T_{1}(1 \mu \mathrm{g} / \mathrm{ml})$ in $10 \mathrm{mM}$ phosphate buffer, $\mathrm{pH} 7.6$ and $0.3 \mathrm{M} \mathrm{NaCl}$ at $37^{\circ} \mathrm{C}$ for $30 \mathrm{~min}$.

When the enzyme products were annealed at increasing RNA inputs, the ribonuclease-resistance of the products increased. At the highest value of $\mathrm{mg} / \mathrm{ml} / \mathrm{hr}$ studied, about $3.7 \%$ of the total enzyme product was hybridized; however, saturation had not been reached (Fig. 4). Higher values of $\mathrm{mg} / \mathrm{ml} / \mathrm{hr}$ were not obtained, since an annealing period of $24 \mathrm{hrs}$ at $72^{\circ} \mathrm{C}$ was adopted to avoid degradation of RNA (10). It is significant that the increased ribonuclease-resistance upon annealing was obtained only when the enzyme products were prepared from reaction mixtures containing the four nucleotide triphosphates. This increase in ribonuclease-resistance observed after annealing is not due to intramolecular self-annealing of the labelled products, but represents the formation of hybrids between labelled products and the added nRNA, probably HnRNA, for the following reasons: 1) Since heat-denaturation of enzyme products followed by rapid cooling failed to increase ribonuclease-resistance, an intermolecular association of labelled products seems likely (e.g., ref. 16). 2) The enzyme products hydrogen-bonded to poly (A)-containing RNA were recovered by oligo (dT)-cellulose column chromatography, indicating that the products were hybridized to poly (A)-containing RNA. It seems unlikely that poly (A)-containing 
RNA is newly synthesized during the in vitro incubation in sufficient amounts to form hybrids with the labelled enzyme product. Therefore, labelled material appears to be hybridized to poly (A)-containing RNA which was added to the reaction mixture. 3) The poly (A) segments of HnRNA molecules were not involved in the hybridization reaction with newly synthesized poly $(U)$, because the treatment of enzyme products with ribonuclease $T_{1}$ before annealing completely abolished the increase in ribonuclease-resistance (Table 4).

TABLE 4. THE EFFECT OF RIBONUCLEASE TREATMENT ON HYBRIDIZATION OF ENZYME PRODUCTS

\begin{tabular}{|c|c|c|c|}
\hline \multicolumn{2}{|c|}{ Ribonuclease treatment } & \multirow{2}{*}{\multicolumn{2}{|c|}{$\begin{array}{l}{ }^{3} \mathrm{H} \text {-labelled } \\
\text { product remaining }\end{array}$}} \\
\hline Before annealing & After annealing & & \\
\hline (with ribonuclease $T_{1}$ ) & (with ribonucleases $T_{1}$ and $A$ ) & $(\mathrm{cpm})$ & $(\%)$ \\
\hline- & - & 5166 & 100 \\
\hline- & + & 86 & 1.7 \\
\hline+ & - & 840 & 16 \\
\hline+ & + & 0 & 0 \\
\hline
\end{tabular}

${ }^{3} \mathrm{H}$-Labelled enzyme products were prepared as described in the text and treated with ribonucleases before and/or after annealing, as indicated. Ribonuclease treatment was carried out as described in Table 3. Hybridization was at $5.0 \mathrm{mg} / \mathrm{ml} / \mathrm{hr}$.

No increase in ribonuclease-resistance after annealing was observed when the products were isolated from reaction mixtures without ATP, GTP and CTP (data not shown here).

Evidence was further obtained that sequences of RNA complementary to those of poly (A)-containing RNA were newly synthesized.

When labelled enzyme products were subjected to fractionation on oligo (dT)cellulose, $13-36 \%$ of the products, depending upon the enzyme preparation used, were found to be associated with poly (A)-containing RNA (Table 5). Since, as

TABLE 5. FraCtionation OF ENZYME PRODUCTS BY OLIGo (DT)-CELlULOSE COLUMN CHROMATOGRAPHY

\begin{tabular}{|c|c|c|c|c|}
\hline \multirow{2}{*}{$\begin{array}{l}\text { Expt. } \\
\text { No. }\end{array}$} & \multirow{2}{*}{$\begin{array}{l}\text { Substrates in reaction } \\
\text { mixture }\end{array}$} & \multirow{2}{*}{$\begin{array}{l}\text { Heat- } \\
\text { denaturation }\end{array}$} & \multicolumn{2}{|c|}{ Fractionation ( $\%$ of total) } \\
\hline & & & $\begin{array}{l}\text { Non-poly (A) } \\
\text { fraction }\end{array}$ & $\begin{array}{l}\text { Poly (A) } \\
\text { fraction }\end{array}$ \\
\hline 1 & ${ }^{3} \mathrm{H}-\mathrm{UTP}$ & - & 95.6 & 4.4 \\
\hline \multirow[t]{2}{*}{2} & ${ }^{3} \mathrm{H}-\mathrm{UTP}+\mathrm{ATP}+\mathrm{GTP}+\mathrm{CTP}$ & - & 64.0 & 36.0 \\
\hline & , $, \quad, \quad$, & + & 96.9 & 3.1 \\
\hline
\end{tabular}

${ }^{3} \mathrm{H}$-Labelled enzyme products were prepared from 5 -fold standard reaction mixtures which contained ${ }^{3} \mathrm{H}$-UTP, unlabelled ATP, GTP and CTP or ${ }^{3} \mathrm{H}-\mathrm{UTP}$ only, as described in the text. The products were fractionated into "poly (A)" and "non-poly (A)" fractions by oligo (dT)-cellulose column chromatography, with or without prior heat-denaturation. See the text for additional details.

mentioned previously, $1.6 \%$ of the total enzyme product was ribonuclease-resistant, only a small portion of the newly synthesized molecule appeared to be hydrogenbonded to poly (A)-containing RNA, the rest of the molecule remaining singlestranded. 
The net increase, $3.4 \%$ in ribonuclease-resistance on annealing at $52 \mathrm{mg} / \mathrm{ml} / \mathrm{hr}$ (see Fig. 4) represents the proportion of newly synthesized material which is complementary to the added RNA. Since, as will be described later, the labelled material associated with poly (A)-containing RNA, comprising $13-36 \%$ of the total enzyme product, is the result of a heteropolymer-synthesizing reaction, it seems that at least $10-26 \%$ of newly synthesized heteropolymers can be hybridized to poly (A)-containing RNA. In our hybridizations, saturation was not reached. Consequently these values would certainly increase on annealing enzyme products at higher values of $\mathrm{mg} / \mathrm{ml} / \mathrm{hr}$. However, the low values obtained here may also in part be due to the complexity of the "template" nRNA added and of the enzyme products.

${ }^{3} \mathrm{H}$-UTP incorporation into the products which are associated with poly (A)-containing RNA showed an almost absolute requirement for all four ribonucleotide triphosphates. Omission of three ribonucleotide triphosphates (ATP, GTP and CTP) resulted in failure to find any labelled material hydrogen-bonded to poly (A)-containing RNA (Table 5). However, due to an apparent stimulation in homopolymer synthesis and/or terminal addition of UMP, this omission did not result in a significant reduction (approximately $20 \%$ ) of the total incorporation into enzyme products (data not shown here). The majority of ${ }^{3} \mathrm{H}$-UMP incorporated in the presence of all four ribonucleotide triphosphates was located internally in the RNA molecule (Table 6). The experiment using $\alpha^{-32} \mathrm{P}$-UTP showed $50.9 \% \mathrm{G}+\mathrm{C}$ content in the product, a

TABLE 6. DISTRIBUTION OF RADIOACTIVITY IN TERMINAL AND INTERNAL POSITIONS OF THE ENZYME PRODUCT

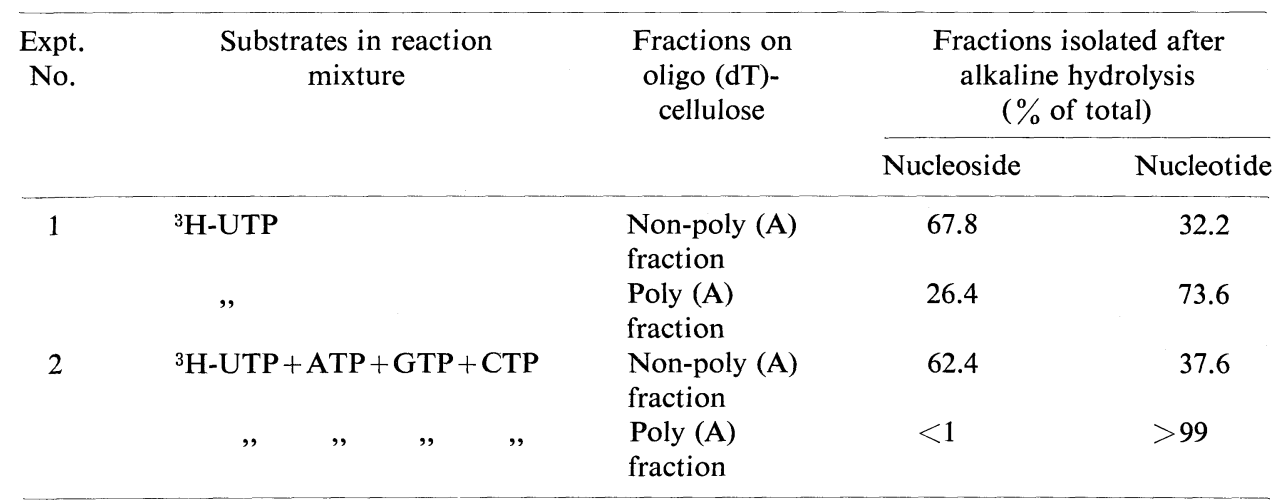

${ }^{3} \mathrm{H}$-Labelled enzyme products were prepared and fractionated as described in Table 5. After alkaline hydrolysis, the radioactivities of nucleoside and nucleotide were analyzed as described in the text.

value similar to that $(50.6-51.3 \%)$ of rat liver $\operatorname{HnRNA}(17,18)$ added to the reaction mixture. These results indicate that the labelled material associated with poly (A)containing RNA represents newly synthesized heteropolymers which are probably RNA transcripts from a poly (A)-containing RNA, HnRNA. In contrast, the labelled material which is not associated with poly (A)-containing RNA has large amounts of terminally added UMP (Table 6 ) and shows low $\mathrm{G}+\mathrm{C}$ content $(23.4 \%)$. The incorporation into this fraction is thus mainly due to terminal addition of UMP, probably to rRNA and tRNA molecules present in the nuclear RNA preparation, and possibly to the formation of homopolymers. 
Taking all of these observations into account, it seems likely that the crude enzyme preparation contains an enzyme(s) which catalyzes the synthesis of RNA transcripts complementary to sequences in poly (A)-containing RNA. In the present experiments, I only found complementary copies to added poly (A)-containing RNA. The homology between the sequence of the products and that of the added RNA was not investigated. Therefore, the question remains whether the enzyme(s) eventually catalyzes the synthesis of copies homologous to added templates. The preparation also exhibits terminal addition of UMP and/or homopolymer synthesis. Recently, the enzyme(s) responsible for RNA-dependent RNA synthesis were purified from crude rat liver preparations by phosphocellulose column chromatography, followed by glycerol gradient centrifugation (19). The results obtained in the preliminary experiments show that the enzymes responsible for heteropolymer synthesis, on the one part, and homopolymer synthesis (and/or terminal addition), on the other, appear to be interrelated.

The biological significance of the discovery of RNA-dependent RNA synthesis in "uninfected" cells should be mentioned here. The possibility of viral origin of the enzyme(s) has not yet been excluded. However, the variety of enzyme sources so far employed (3, 5-9) and the template specificity of the enzymes suggest that viral origin is unlikely.

An attractive hypothesis is that a cell possesses a message amplification system in which the RNA-dependent RNA polymerase plays a vital role (4). The finding of the enzyme(s) in "uninfected" rat liver cells indicates that this mechanism may be part of fundamental regulatory machinery of the cell, and not be restricted to enucleated cells (8). With respect to this hypothesis, high template activity of mRNA and nRNA is of particular interest. HnRNA contains a long poly (A) segment at the 3'-end and is thought to be a precursor of cytoplasmic mRNA $(20,21)$. The fact that only mRNA and nRNA are very active templates for RNA-dependent RNA synthesis is in accord with the concept of message amplification: only mRNA and messenger-like RNA (or possibly particular species of mRNA) may be selectively recognized and amplified. In this communication, however, it would be premature to discuss this hypothesis in detail. Further experiments are certainly needed for a better understanding of RNAdependent RNA synthesis.

Acknowledgements. The author is indebted to Miss J.M. Whitelam for her helpful assistance.

\section{REFERENCES}

1. Chamberlin, M. Transcription 1970: A summary. Cold Spring Harbour Symp. Quant. Biol. 35, $851-873,1970$

2. Sugiyama, T., B.D. Kurant and K.K. Lonberg-Holm. RNA virus gene expression and its control. Ann. Rev. Microbiol. 26, 467-502, 1972

3. Burdon, R.H. and R.M. SMellie. The incorporation of uridine-5'-triphosphate into ribonucleic acid by enzyme fractions from Ehrlich ascites carcinoma cells. Biochim. Biophys. Acta 51, 153-162, 1961

4. NAOrA, H. RNA synthesis and nuclear-cytoplasmic interaction. Protein, Nucleic Acid and Enzyme 7, 372-381, 1961

5. Wilkie, N.M. and R.M.S. Smellie. Chain extension of ribonucleic acid by enzymes from rat liver cytoplasm. Biochem. J. 109, 485-494, 1968

6. Astier-MAnifacier, S. and P. CoRnUet. RNA-dependent RNA polymerase in chinese cabbage. Biochim. Biophys. Acta 232, 484-493, 1971 
7. Duda, C.T., M. Zaitlin and A. Siegel. In vitro synthesis of double-stranded RNA by an enzyme system isolated from tobacco leaves. Biochim. Biophys. Acta 319, 62-71, 1973

8. Downey, K.M., J.J. Byrnes, B.S. Jurmark and A.G. So. Reticulocyte RNA-dependent RNA polymerase. Proc. Natl. Acad. Sci. U.S. 70, 3400-3404, 1974

9. Mikoshiba, K., Y. Tsukada, I. Haruna and I. Watanabe. RNA-depeudent RNA synthesis in rat brain. Nature 249, 445-448, 1974

10. NaORa, H., J.M. Whitelam, R.P. Monckton and R.E.H. Wettenhall. DNA sequences from which double-stranded RNA is transcribed. In The Eukaryote Chromosome ed. Peacock, W.J. and R.D. Brock, A.N.U. press, Canberra, pp. 217-232, 1975

11. Monckton, R.P. and H. NAOrA. Rat liver double-stranded RNA from nuclei and whole cells: Isolation, purification and characterization. Biochim. Biophys. Acta 335, 139-154, 1974

12. Haruna, I., T. Ohno, N. Hozumi and I. Watanabe. RNA-dependent RNA polymerase from leukemia and ascites tumour cells. Gann Monograph on Cancer Research 12, 203-211, 1972

13. NaOra, H. and K. Kodaira. Interaction of informational macromolecules with ribosomes. I. Binding of labelled nuclear RNA by rat liver ribosomes. Biochim. Biophys. Acta 182, 469—480, 1969

14. Weissman, C., G. FeiX and H. Slor. In vitro synthesis of phage RNA: The nature of the intermediates. Cold Spring Harbour Symp. Quant. Biol. 33, 83-100, 1968

15. Тнасн, S.S. and R.E. Tнасн. Mechanism of viral replication. I. Structure of replication complexes of R17 bacteriophage. J. Mol. Biol. 81, 367-380, 1973

16. JelineK, W. and J.E. DARnell. Double-stranded regions in heterogeneous nuclear RNA from Hela cells. Proc. Natl. Acad. Sci. U.S. 69, 2537-2541, 1972

17. OKamura, N. and H. Busch. Base composition of high molecular weight nuclear RNA of Walker tumour and liver of the rat. Cancer Res. 25, 693-697, 1965

18. Muramatsu, M., J.L. Hodnett and H. Busch. Base composition of fractions of nuclear and nucleolar ribonucleic acid obtained by sedimentation and chromatography. J. Biol. Chem. 241, 1544 - 1550, 1966

19. Monette, J.P.L. and H. Naora. Purification and characterization of an RNA-dependent RNA polymerase from normal rat livers. Proc. Aust. Biochem. Soc. 8, 86, 1975

20. Darnell, J.E., W.R. JelineK and G.R. Molloy. Biogenesis of mRNA: Genetic regulation in mammalian cells. Science 181, 1215-1221, 1973

21. Molloy, G.R., W. Jelinek, J. Salditt and J.E. Darnell. Arrangement of specific oligonucleotides within poly (A)-terminated HnRNA molecules. Cell 1, 43-53, 1974 